\title{
Translocation of Ultramarine Lories Vini ultramarina in the Marquesas Islands: Ua Huka to Fatu Hiva
}

\author{
C. KUEHLER, A. LIEBERMAN, A. VARNEY, P. UNITT, R. M. SULPICE, \\ J. AZUA and B. TEHEVINI
}

\begin{abstract}
Summary
The Ultramarine Lory (Ultramarine Lorikeet, Marquesas Lorikeet, Pihiti) Vini ultramarina is one of the most threatened insular Lory species. Endemic to the Marquesas Islands, where it probably once ranged throughout the archipelago, it has been nearly extirpated from all but the tiny island of Ua Huka. Given the vulnerability of a single population inhabiting one small island, and the decline of the species in recent years, establishment of the Ultramarine Lory on another less disturbed island within its historic range has been proposed as a conservation strategy. This paper describes a 1991 survey evaluating the status of the Ultramarine Lory in the Marquesas Islands, and three subsequent translocations of birds from the island of Ua Huka to the island of Fatu Hiva. Twenty-nine birds were relocated during the period from 1992 to 1994 at the request of the Delegation de L'Environnement, French Polynesia. A preliminary survey, prior to the third translocation, indicates that previbusly transferred birds are surviving and may be reproducing; an intensive survey is planned in 1997.
\end{abstract}

\section{Introduction}

More species of eastern Polynesian landbirds have become extinct since the arrival of humans than currently survive in the islands today (Steadman 1989). Sixteen endemic species inhabiting French Polynesia are considered threatened or endangered (Thibault 1988; Collar et al. 1994). This conservation crisis facing island birds is not restricted to Polynesia alone. Of the 93 species and 83 subspecies of birds which have become extinct since $160093 \%$ lived on islands (King 1985). Elsewhere in the Pacific, the Hawaiian Islands are home to 31 endangered bird taxa, 12 of which number less than 100 individuals (U.S. Fish and Wildlife Service 1994). Pacific island birds are struggling against the devastating effects of introduced predators, herbivores, plants, disease and habitat disturbance that accompanied the arrival of humans into their fragile, small, isolated ecosystems.

\section{Past and present distribution of the Ultramarine Lory}

In 1991, current information describing the distribution and status of the Ultramarine Lory (Ultramarine Lorikeet, Marquesas Lorikeet, Pihiti) Vini 


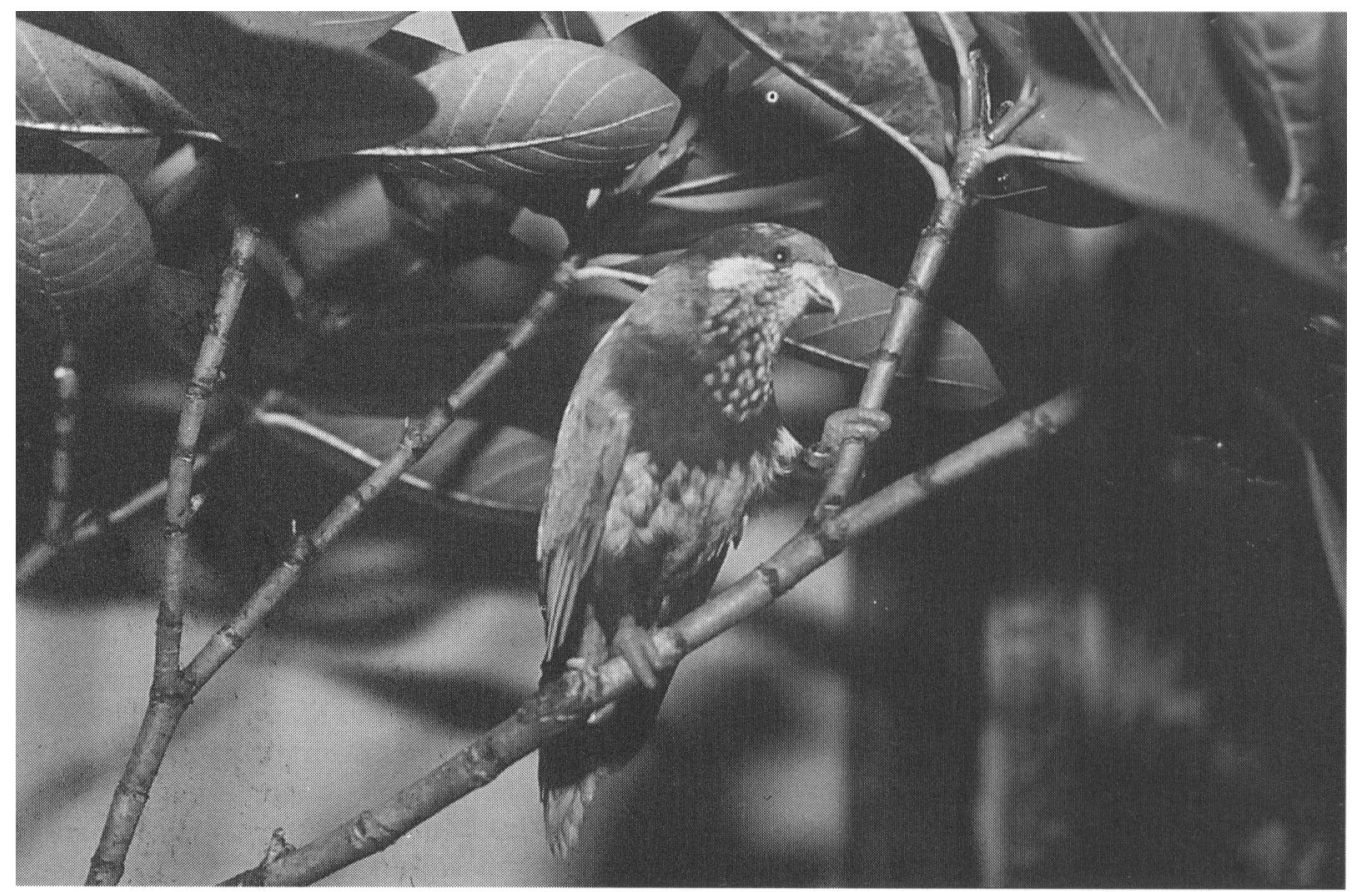

Figure 1. Ultramarine Lory Vini ultramarina.

ultramarina in the Marquesas Islands was fragmented. On the basis of fossil and archeological remains Steadman (1989) reported that before the arrival of humans, most or all species of flying birds in the Marquesas were found throughout the island chain. However, since the arrival of colonists, the diversity of species has been decreasing. Observations by Holyoak (1975) and Holyoak and Thibault (1984) in the 1970s reported the Ultramarine Lory to be scarce and localized on Nuku Hiva (40-150 individuals in 1972), widespread and fairly common on Ua Pou (250-350 pairs in 1975), and fairly common on Ua Huka (200-250 pairs in 1975). On Ua Huka, the population reportedly descends from two birds originating from $\mathrm{Ua}$ Pou and released on Ua Huka in 1941 (Decker 1980, L. Lichtle verbally; Figure 1).

More recently, the situation was summarized by Thibault (1988) and Seitre and Seitre (1991), who reported that the Lory was declining and restricted to higher elevations on both Nuku Hiva, where it may have been completely extirpated, and Ua Pou, where it was very rare. In contrast, they noted that the introduction of birds on Ua Huka in 1941 resulted in a population which was thriving even at lower elevations.

\section{Translocation programme}

Because of the decline of the Ultramarine Lory in its historic range, a conservation programme was initiated in 1990. The goals of the programme were to evaluate the status of the Ultramarine Lory and establish an additional population via translocation efforts if necessary. Transferral of birds from one 
site to another to establish a second population has been used successfully for several species, e.g. New Zealand Saddlebacks Philesturnus carunculatus, Chatham Island Black Robins Petroica traversi, Chatham Island Snipes Coenocorypha aucklandica pusilla and Seychelles Warblers Acrocephalus sechellensis (Merton 1966a,b, 1975; Komdeur et al., 1991; Butler and Merton 1992). The successful accidental introduction of Ultramarine Lories from $\mathrm{Ua}$ Pou to Ua Huka suggested that the Lory was a good candidate for translocation.

\section{Methods}

Survey of Ultramarine Lories in the Marquesas Islands

Prior to the decision that translocation of Lories from Ua Huka to Fatu Hiva was beneficial, a survey was conducted in 1991 to evaluate the status of the species in its historic range. On Ua Pou, Ua Huka and Nuku Hiva, one week was spent on each island, 19 November 1991-11 December 1991. All field efforts were focused in habitats likely to support Lories, namely forests and plantations. Grasslands, scrub and low woodland dominated by acacia Leucaena sp. were avoided. Attempts were made to count as precisely as possible the number of Lories seen and heard, identify foraging trees and calculate the number of birds seen per hour. These counts were multiplied by the time spent searching, an estimate of the area covered per hour, and the fraction of the island covered with suitable habitat (estimated from aerial photographs). Estimates of the area covered per hour were dependent on two factors. First, the width of the swath in which, on average, all Lories were counted; 100 and $200 \mathrm{~m}$ were chosen as the figures on which estimates were based. A calling Lory can be heard at a distance of over $100 \mathrm{~m}$ and the birds are highly vocal, but a silent Lory can easily pass undetected in the crown of a coconut palm. Second, a value for the observer's rate of movement through the habitat was chosen; this rate varied from 0.5 to $2.0 \mathrm{~km} /$ hour. Again, two values were chosen, 1.0 and $1.5 \mathrm{~km} /$ hour, as bases for estimates. Finally, minimum population estimates were calculated from evaluation of available habitat and the number of birds seen per hour (density) (Franzreb 1981).

\section{Capture of Lories on Ua Huka}

Foraging and flight patterns of Ultramarine Lories on Ua Huka were evaluated to develop capture techniques. Because food resources (cultivated and wild) were widespread throughout the island, and birds did not consistently feed in specific areas, it was difficult to predict where mist-nets should be erected. Capture sites were selected around food trees (Table 1). Nets were erected to take advantage of the anticipated flight patterns of the birds, the angle of the sun, as well as the proximity to base camp to minimize transport time from nets to field cages.

All the mist nets used were $2.1 \mathrm{~m}$ in width (five panels) and ranged from 5.1 to $18.3 \mathrm{~m}$ in length. They were erected at various heights according to the food source that was being exploited. Musa sp. and Spondias dulcis trees required a low to medium net that was typically raised $1.0-3.0 \mathrm{~m}$ off the ground. Mangifera 
Table 1. Food items observed to be eaten by Ultramarine Lories Vini ultramarina in the wild, Ua Huka 1991-1994.

\begin{tabular}{lcc}
\hline Plant species & Fruit & Flower/Nectar \\
\hline Calophyllum inophyllum & $\mathrm{X}$ & $\mathrm{X}$ \\
Carica papaya & $\mathrm{X}$ & \\
Casuarina equisetifolia & & $\mathrm{X}$ \\
Citrus sinensis & & $\mathrm{X}$ \\
Cocos nucifera & & $\mathrm{X}$ \\
Coffea arabica & $\mathrm{X}$ & $\mathrm{X}$ \\
Cordia subcordata & & $\mathrm{X}$ \\
Coroza oleifera & & $\mathrm{X}$ \\
Erythrina sp. & & $\mathrm{X}$ \\
Eugenia malaccensis & & $\mathrm{X}$ \\
Guettarda speciosa & $\mathrm{X}$ & $\mathrm{X}$ \\
Hibiscus tiliaceus & & $\mathrm{X}$ \\
Inga edulis & & $\mathrm{X}$ \\
Mangifera indica & $\mathrm{X}$ & $\mathrm{X}$ \\
Morinda citrifolia & $\mathrm{X}$ & \\
Musa sp. & & $\mathrm{X}$ \\
Pisonia grandis & & $\mathrm{X}$ \\
Pometia pinnata & & $\mathrm{X}$ \\
Psidium guajava & & \\
Syzygium malaccenge & & \\
Tectona grandis & & \\
Spondias dulcis & &
\end{tabular}

indica, Pometia pinnata, and Inga edulis required high nets that were raised from 4.0 to $6.0 \mathrm{~m}$ off the ground by means of lengths of bamboo or ropes and pulleys. Generally, mist nets were opened within one hour of daylight and closed at dusk. Netting effort was calculated as mist-net hours.

\section{Behaviour and husbandry during transport}

Wild-caught Lories were immediately removed from mist nets and transferred to small cloth bags for transport in the field. Birds were then housed individually in $30.5 \times 30.5 \times 30.5-\mathrm{cm}$ wooden field cages. Each cage had a wire front and bottom, allowing for observations and maintenance. Separation of birds eliminated aggressive interactions and facilitated observations of feeding behaviour.

All Lories were fed a liquid diet, Nekton Lory (Nekton, Pforzheim, Germany) and papaya. In 1992, birds were misted several times daily with a fine spray. Insufficient misting in 1993 resulted in one of the birds developing soiled feathers and subsequent flying difficulties after release. This bird was found dead several days after translocation. Birds were misted more frequently in 1994 and feather condition was evaluated prior to relocation. In 1992 and 1993, Lories were banded, weighed and measured (Baldwin et al. 1931) prior to relocation. Collection of measurement data was eliminated in 1994 to minimize stress from handling but banding and weighing of birds was continued.

Ultramarine Lories were held in captivity until sufficient birds were caught for the translocation (five to seven days depending on the day of capture). 


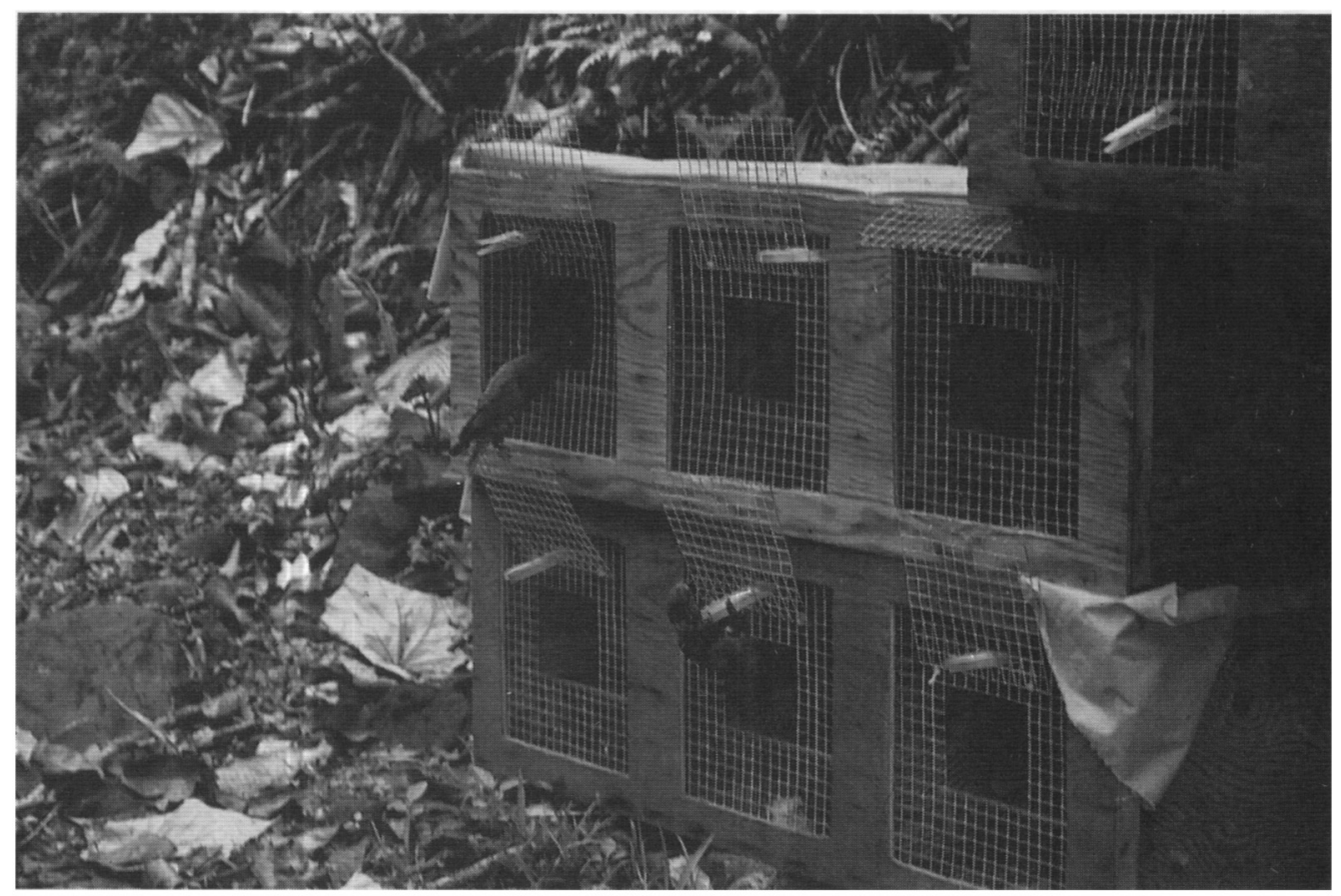

Figure 2. Release of Ultramarine Lories Vini ultramarina on Fatu Hiva.

Observations were made to ensure that birds were feeding adequately prior to relocation. Transport by boat from Ua Huka to Fatu Hiva took approximately seven to nine hours, depending on wind and ocean conditions. Efforts were made to keep the field cages out of the sun and ocean spray.

\section{Liberation and monitoring}

After arrival at Fatu Hiva, the birds were fed, misted and isolated against further disturbance. In 1992, the morning following arrival, the birds were given fresh food and allowed three hours to feed prior to release. In 1993 and 1994, the birds were released on the third day after arrival, allowing time for a search for previously translocated birds. At mid-morning during all three translocations, the cages were transported by truck and portage to a location approximately $2.0 \mathrm{~km}$ inland and upriver from the village of Omoa where they were released (Figure 2). Release site selection was based on the presence of food resources similar to those the birds were observed utilizing on Ua Huka (Table 1). This was based on Service de L'Economie Rurale (SER) surveys of the island (B. Tehevini unpubl. data).

Prior to the second translocation (1993), the Omoa Valley was surveyed to locate Lories (or their offspring) from the previous translocation (1992). In 1994, a second survey was conducted prior to the release of new birds to search for birds and their offspring from the previous two years. During the year between translocation efforts, protection and monitoring was the responsibility of the SER, Fatu Hiva. 
Table 2. Survey of Ultramarine Lories Vini ultramarina on Ua Huka, Marquesas Islands, in diverse habitats, 1991.

\begin{tabular}{|c|c|c|c|c|c|}
\hline Date & Locality & Hours & $\begin{array}{l}\text { Number of } \\
\text { birds seen }\end{array}$ & Density & $\begin{array}{l}\text { Habitat } \\
\text { type }\end{array}$ \\
\hline 29 November & Hokatu Valley & 6 & 80 & $13 \cdot 3$ & FP \\
\hline 30 November & Hane Valley & $5 \cdot 5$ & 45 & 8.2 & FP \\
\hline 1 December & Vaipee Valley (low) & 2 & 15 & $7 \cdot 5$ & GV \\
\hline 2 December & $\begin{array}{l}\text { Service Economie Rurale } \\
\text { Garden (SER) }\end{array}$ & 0.75 & 7 & $9 \cdot 3$ & GV \\
\hline 2 December & Vaipee Valley (low) & 0.5 & 3 & 15.0 & FP \\
\hline 3 December & $\begin{array}{l}\text { Vaipee Valley } \\
\text { (high, west side) }\end{array}$ & 2 & 40 & 20.0 & FP \\
\hline 4 December & $\begin{array}{l}\text { Plateau between SER and } \\
\text { Vaipee valley }\end{array}$ & 1.5 & 15 & 10.0 & DF \\
\hline 4 December & Path, east slope of Vaipee & 0.5 & 11 & 22.0 & FP \\
\hline 4 December & Vaipee valley (low) & 0.5 & 3 & 6.0 & GV \\
\hline
\end{tabular}

FP, Mixed forest plantations dominated by coconut palms Cocos nucifera, hibiscus Hibiscus tiliaceus, banana trees Musa sp., mango trees Mangifera indica, with a wide variety of other, less numerous species: breadfruit Artocarpus altilis, banyan fig Ficus benghalensis, pandanus Pandanus tectorius, mape Inocarpus fagifer, kava Pometia pinnata, kapok Ceibe pentandra, aeho Miscanthus floridulus, bamboo Gramineae banbuseae, ahia Syzygium malaccense, tamanu Calophyllum inophyllum, motoi Cananga odorata, papaya Carica papaya, ihi Portulaca lutea, and noni Morinda citrifolia.

GV, Gardens and villages with many of the same species listed above but at a lower density.

DF, Drier forest, more open woodland on slopes with shorter hibiscus trees some guava Psidium guajava and casuarina Casuarina equisetifolia

\section{Results}

Survey of Ultramarine Lories in the Marquesas Islands: Ua Pou, Nuku Hiva and Ua Huka

Despite all efforts, no Ultramarine Lories were observed on Ua Pou even though the species was common there 16 years ago. Only the word of a few local residents suggests the species survives on this island in very small numbers. The situation on Nuku Hiva was equally disappointing. No Ultramarine Lories were observed and most residents were either ignorant of the species or denied its existence on their island. The most recent report was of a single individual along the road between Taiohae and Taipivi in May 1991. Any population of the Lory remaining on Ua Pou and Nuku Hiva is so low as probably to be no longer self-sustaining.

The Ultramarine Lory remains common on Ua Huka in suitable habitat. A total of 313 birds was counted. Comparisons of birds seen per hour (density) were made in diverse habitats (Table 2). The Lory is most abundant in mixed forest/plantation (11.8-22.o birds per hour). Ua Huka covers $78 \mathrm{~km}^{2}$, of which approximately half is suitable habitat for Lories. In the field, the Hokatu Valley, consisting largely of prime habitat, was assessed as containing at least 100 birds (actual count 80 ). The Lory habitat there covers approximately $1.5 \mathrm{~km}^{2}$. If the species's density throughout the remaining forested sections of Ua Huka is half that of the Hokatu Valley, this rough assessment suggests a population of approximately 1300 birds $[(100$ birds $/ 1.5 \mathrm{~km}) / 2] \times 40 \mathrm{~km}^{2}$ suitable habitat $=$ 1333, consistent with the actual count of slightly over 300 birds. A minimum 
estimate is 800 birds [ 6 birds/hour $\times$ observer speed $1.5 \mathrm{~km} /$ hour $)-\left(40 \mathrm{~km}^{2}\right.$ suitable habitat $) \times(6$ birds/hour $) /($ observer speed $1.5 \mathrm{~km} /$ hour $) / 0.2 \mathrm{~km}$ width of detection zone]. The greatest densities observed in many areas (Table 2) suggest the total population exceeds this minimum. On the basis of previous reports and this evaluation of the disappearance of the Ultramarine Lory in its historic range, the Délégation de l'Environnement, French Polynesia, requested the initiation of a relocation programme of birds from Ua Huka to establish a satellite population on Fatu Hiva.

\section{Capture and translocation}

A total of 29 Ultramarine Lories were translocated from Ua Huka to Fatu Hiva in three shipments in 1992-1994. Twenty-seven of these birds were captured using mist-nets, and two birds were captured as juveniles fouled with sap from a Pisonia grandis tree. A total of 893 mist-net hours was spent attempting to capture Lories (347 in 1992, 441 in 1993, and 105 in 1994). The most successful netting attempts were in areas with blooming Inga edulis and Spondias dulcis trees. Ultramarine Lories tolerated captivity and transport well and all birds began eating within 48 hours of capture. Juveniles began eating sooner than adults and exhibited fewer stress-related behaviours (pacing and rubbing against the wire). The two problems encountered during translocation included identifying potential capture sites (based on foraging activities) and providing a captive environment that decreased feather soiling while birds were eating a nectar-based diet. Insufficient misting during the 1993 translocation probably resulted in one bird dying after release because of poor flying capabilities caused by soiled feathers.

\section{Liberation and monitoring}

Twenty-nine Ultramarine Lories were released from three translocations on 28 August 1992 (7 birds), 24 November 1993 (7 birds), and 23 October 1994 (15 birds). After the field cages were opened, birds flew directly to the crowns of nearby coconut palms and began feeding on the flowers. Generally, they perched from several minutes to an hour, preening and vocalizing with their release-mates. The Ultramarine Lories stayed in pairs or small groups, flying in noisy flocks up and down the Omoa Valley.

On 23 November 1993, prior to the release of birds from the second translocation, a survey of the Omoa Valley was conducted and four Lories were observed above the village. In 1993 and 1994, during the period between relocation shipments, birds were monitored by the SER. On 22 October 1994, prior to the third translocation, a more intensive survey of the Omoa Valley resulted in the observation of 14 birds. Thirteen was the known total number of Ultramarine Lories that had been successfully transferred from Ua Huka to Fatu Hiva in 1992 and 1993. Additionally, in 1994 the SER recorded that several Omoa villagers reported seeing Lories in Hanaveve and Pupuauwihi Valley. On 14 October, 1994, five birds were seen at eye level feeding on "wild" banana. The Lories were described as having dark blue/black plumage and "all blue on the face and front". This is an accurate description of juvenile Ultramarine Lories, 
Table 3. Sightings of Ultramarine Lories Vini ultramarina on Fatu Hiva, Marquesas Islands, after translocation from Ua Huka.

\begin{tabular}{llccl}
\hline Date & Locality & $\begin{array}{c}\text { Number of } \\
\text { birds seen }\end{array}$ & $\begin{array}{c}\text { Number of } \\
\text { birds heard }\end{array}$ & Observer \\
\hline 23 November 1993 & Omoa & 2 & 2 & $\begin{array}{l}\text { A. Lieberman, A. Varney, } \\
\text { J. Azua }\end{array}$ \\
20 January 1994 & Omoa & 4 & 4 & $\begin{array}{l}\text { T. Bernard } \\
\text { 24 January 1994 }\end{array}$ Omoa \\
2 February 1994 & Omoa & 4 & 2 & K. Roger \\
17 March 1994 & Omoa & 2 & 2 & 4 local citizens \\
23 March 1994 & Omoa & 4 & 4 & T. Bernard \\
October 1994 & Hanaveve and & 4 & 2 & T. Bernard \\
& Pupuauwihi & 3 & 0 & Y. Taputu \\
14 October 1994 & Omoa & 5 & & Y. Taputu \\
28 March 1994 & Omoa & 6 & 6 & T. Bernard \\
22 October 1994 & Omoa & 7 & 7 & C. Kuehler, A. Lieberman, \\
& & & & A. Varney \\
\hline
\end{tabular}

which would be the result of reproduction in the wild flock ( $Y$. Taputu verbally). These preliminary results indicate that the translocated birds are surviving and reproducing on Fatu Hiva (Table 3).

\section{Discussion}

The 1991 survey found that the effective current range of the Ultramarine Lory was restricted to one island, Ua Huka. On the basis of draft recommendations by the ICBP/IUCN/CBSG Parrot Action Plan for Vini ultramarina, recommendations by biologists familiar with French Polynesia, and at the request of the Delegation de L'Environnement, a translocation programme was developed to capture and relocate birds to a less disturbed island (Seal et al. 1992, R. Hay in litt., J.-C. Thibault verbally, P. Raust verbally, A. Varney unpubl. data).

The island of Fatu Hiva was chosen as the site to establish a satellite population of Ultramarine Lories for biological, political and practical reasons. Biologically, selection of a rat-free island was considered the highest priority; introduced black rats Rattus rattus, which prey on eggs and chicks, are probably the greatest cause of the Lory's decline on Nuku Hiva and Ua Pou. Decreased habitat due to agriculture and grazing herbivores, tropical storms, competition with introduced species of honeybees, and disease afflicting banana flowers may have also contributed to the decline. However, harbour improvement on Nuku Hiva and $\mathrm{Ua}$ Pou allowing the influx and establishment of rats is probably the major problem (Seitre and Seitre 1992, T. Kautai verbally, L. Lichtle verbally).

The alternative islands of Tahuata, Eiao and Mohotani were not considered as potential release sites because black rats have been trapped on Tahuata, and Eiao and Mohotani are badly degraded by overgrazing (Montgomery et al. 1980, Hay 1986, Seitre and Seitre 1992, P. Unitt unpubl. data). Ua Huka and Fatu Hiva do not have established populations of $R$. rattus. The Polynesian rat Rattus exulans is the only resident species and is probably not as detrimental to Vini Lories as the more aggressive black rat (M. Robert verbally, Atkinson 1985, Seitre and Seitre 1992, R. M. Sulpice unpubl. data). Additionally, Fatu Hiva 
does not have an airport or improved harbour and wharf, nor are there plans for one in the future which would facilitate rat introduction. Major portions of the $80-\mathrm{km}^{2}$ island still support suitable habitat for Lories and the preferred food items available on Ua Huka are also present on Fatu Hiva (SER unpubl. data).

Politically and practically, Fatu Hiva was chosen as the site for a secondary Lory population because it is the most undisturbed Marquesas island that supports a small human population (approx. 500) (Stanley 1989). Although it can be argued that translocations should attempt to establish populations of endangered or threatened birds in uninhabitated areas, sparsely populated islands offer some advantages. Monitoring and protection of recently introduced birds requires labour, money and interest. The local government of Fatu Hiva employs a SER staff member (B. Tehevini) who resides permanently on Fatu Hiva and was willing to monitor and safeguard the birds. The authors felt that if long-term conservation efforts for the Ultramarine Lory were going to succeed after their departure, education, involvement and partnership with the local people was essential (Hay 1986). Translocation of birds from Ua Huka to Fatu Hiva was supported by the mayors of both islands. Additionally, efforts were made to include the communities through presentations and written literature.

Single populations of threatened and rare island bird species are at great risk of extinction. As Cade (1986) pointed out, "conservationists cannot be passive that is, protection of habitat, the setting aside of nature preserves alone, will not suffice, because such preservation simply cannot occur on a large enough scale to take care of everything". Translocation is a valuable conservation strategy that has the greatest potential for success and least impact on the donor population, if it is implemented before the species is critically endangered and only a few individuals remain (Griffith et al. 1989).

Preliminary results from our three translocations of Ultramarine Lories from Ua Huka indicate that relocated birds are surviving on Fatu Hiva. Continual monitoring is essential and an intensive survey, planned for 1997, will evaluate the success of the programme by determining if the transplanted population is reproducing and growing. Hopefully, the experience gained from this programme will prove valuable to future translocation programmes for other threatened species of Lories.

\section{Acknowledgements}

The authors would like to acknowledge the support of the people of French Polynesia and France who made this programme possible: Jean-Claude Thibault, Jean-Michel Sionneau, Philippe Raust, Philippe Siu, Claude Monnet, Michel Guerin, Leona Sanford, Leon Lichtle, Paolo Mambretti, Benjamin Teikihuavanaka, Petrano Rogatien, Yolande Vernaudon, Theodore and Noeline Teinauri, Teiki Falchetto, Kamia Kehu, Ossan, Lucien and Leo Ruhe, Guy Rozy, Lucien Kimitete, Willie Tetuanui, Dolores Sulpice, Hubert and Sabine Fournier, Jean-Jacques Teaurai and family, Jean-Pierre Timau Kautai, Serge Amiot, Veronique Mu Lippman, Yolande Taputu, Professor Tia and the Omoa Elementary School. A special thanks to Mary Robert for her unpublished data on rats in French Polynesia. The Polynesia Lory Project was funded by the Zoological Society of San Diego and the Délégation de l'Environnement, French Polynesia. 
Additional biological staff support was donated by the Peregrine Fund, Inc. and the San Diego Natural History Museum.

\section{References}

Atkinson, I. A. E. (1985) Spread of commensal species of Rattus to oceanic islands and their effects on island avifaunas. Pp. $35^{-81}$ in P.J. Moors, ed. Conservation of island birds. Cambridge, U.K.: International Council for Bird Preservation (Techn. Publ. 3).

Baldwin, S. P., Oberholser, H. C. and Worley, L. G. (1931) Measurements of birds. Cleveland, Ohio: Scientific Publications of the Cleveland Museum of Natural History, Vol. II.

Butler, D. and Merton D. (1992) The Black Robin: Saving the world's most endangered bird. Auckland, N.Z.: Oxford University Press.

Cade, T. J. (1986) Reintroduction as a method of conservation. Raptor Res, 5: 72-84.

Collar, N. J., Crosby, M. J. and Stattersfield, A. J. (1994) Birds to watch 2: The ICBP world list of threatened birds. Cambridge, U.K.: Birdlife International.

Decker, B. (1980) The probable introduction of the Ua Pou blue lorikeet to Ua Huka. Elepaio 41: 8.

Franzreb, K. E. (1981) The determination of avian densities using the variable-strip and fixed width transect surveying methods. Stud. Avian Biol. 6: 139-145.

Griffith, B., Scott, J. M., Carpenter, J. W. and Reed, C. (1989) Translocation as a species conservation tool: status and strategy. Science 245: 477-480.

Hay, R. (1986) Bird conservation in the Pacific islands. Cambridge, U.K.: International Council for Bird Preservation (Study Report 7).

Holyoak, D. T. (1975) Les oiseaux des Marquises. L'Oiseau et RFO 45: 207-233, 341-366.

Holyoak, D. T. and Thibault J. C. (1984) Contribution a l'étude des oiseaux des Polynesie Orientale. Paris: Memoires du MNHN.

King, W. B. (1985) Island birds: will the future repeat the past? Pp. 3-15 in P. J. Moors, ed. Conservation of island birds. Cambridge, U.K.: International Council for Bird Preservation (Techn. Publ. 3).

Komdeur, J., Bullock, I. D. and Rands, M. R. W. (1991) Conserving the Seychelles Warbler Acrocephalus sechellensis by translocation: a transfer from Cousin Island to Aride Island. Bird Conserv. Internatn.1: 177-185.

Merton, D. V. (1966a) Transfer of Saddleback from Hen Island to Middle Chicken Island, January, 1964. Notornis 12: 213-222.

Merton, D. V. (1966b) Some observations of feeding stations, food and behavior of the North Island Saddleback on Hen Island in January. Notornis 13: 3-6.

Merton, D. V. (1975) Success in reestablishing a threatened species: the Saddleback: its status and conservation. ICBP Bull XII: $150-158$.

Montgomery, S. L.; Gagne, W. C. and Gagne, B. H. (1980) Notes on birdlife and nature conservation in the Marquesas and Society islands. Elepaio 40: 152-155.

Seal, U. S.; Wirth, R.; Thomsen, J.; Joseph, Ellis, S. and Collar, N. (1992) Parrot CAMP (Conservation Assessment and Management Plan) 14-17 January 1992. Workshop Report: Draft Review Edition. Cambridge, U.K.: ICBP/IUCN/SSC Parrot Specialist Group.

Seitre, R. and Seitre, J. (1991) Causes of land-bird extinctions in French Polynesia. Noumea, New Caledonia: South Pacific Regional Environment Program Occasional Paper Series No. 8.

Seitre, R. and Seitre, J. (1992) Causes of land-bird extinctions in French Polynesia Oryx 26: 215-222.

Stanley, D. (1989) Tahiti - Polynesia. Chico, California: Moon Publications.

Steadman, D. W. (1989) Extinction of birds in eastern Polynesia: a review of the record, and comparisons with other Pacific island groups. J. Archaeol. Sci. 16:177-205. 
Thibault, J.-C., ed. (1988) Menaces et conservation des oiseaux de Polynesie française. In Livre Rouge des Oiseaux Menaces des Regions Françaises d'Outre-Mer. Cambridge, U.K.: International Council for Bird Preservation (Monogr. 5).

U.S. Fish and Wildlife Service (1994) Listed, Proposed or Candidate Species under the U.S. Endangered Species Act. July 28, 1994. Washington, D.C.: U.S. Fish and Wildlife Service.

C. KUEHLER

The Peregrine Fund, Inc. P.O. Box 39, Volcano, Hawaii 96785, U.S.A.

\section{A. LIEBERMAN}

The Peregrine Fund, Inc. P.O. Box 39, Volcano, Hawaii 96785, U.S.A.

\section{A. VARNEY}

Délégation de l'Environnement, B.P. 590, Papeete, Tahiti, French Polynesia.

P. UNITT

San Diego Natural History Museum, P.O. Box 139o, San Diego, California 92112, U.S.A.

R. M. SULPICE

Service de l'Economie Rurale, Hokatu, Ua Huka, Marquesas Islands, French Polynesia.

J. AZUA

Zoological Society of San Diego, P.O. Box 551, San Diego, California 92112, U.S.A.

B. TEHEVINI

Service de l'Economie Rurale, Omoa, Fatu Hiva, Marquesas Islands, French Polynesia. 